\title{
Out-of-Class English Language Learning Strategies Used by English Majors in Indonesia
}

\author{
Haryanti \\ Syarif Hidayatullah State Islamic University Jakarta, Jl. Ir. H. Djuanda 95, Ciputat, Indonesia \\ Corresponding e-mail: haryanti@uinjkt.ac.id
}

\begin{abstract}
This study aimed to investigate out-of-class language learning strategies (OCLLSs, henceforth) used by six English majors in Indonesia. The data used in this study were the students' journals written for seven days and email-based interview results. The study found that the two most common strategies used by the students when learning English outside the classroom were strategies related to writing and reading skills. Students reported using writing and reading skills related strategies to work on their undergraduate thesis and prepare the teaching materials for the teaching practice. The study also revealed that the students tended to use tools when performing OCLLSs. It was also found that the modern technology-affiliated tools (e.g. computer, Instagram) were the most favourite tools chosen by the students.
\end{abstract}

Keywords: English, learning strategies, out-of-class, writing, reading, modern technology

\section{INTRODUCTION}

The status of English as a foreign language in Indonesia seems to have determined how it is treated either in academic or in social life. Although English is stated as a compulsory subject learnt at secondary and tertiary education levels in Indonesia (Lauder, 2008 cited in Mattarima \& Hamdan, 2011), the portions of time given for English lessons are still very limited. Students only learn English for three to four hours each week at secondary schools (Lamb, 2002; Mattarima \& Hamdan, 2011; Novera, 2004) and for maximum four credits at university levels if they are not English majors (Lamb, 2002).

Hence, the students often find it difficult to read and understand majors' related textbooks written in English, thereby hinders their opportunities to further learn the language (Lamb, 2002). Moreover, the English exposure provided in in-class learning is very limited because the language used to teach English at school and university is mostly Bahasa Indonesia (Lamb, 2002; Mustafa, 2001 cited in Novera, 2004; Dardjowidjojo, 2003 cited in Mattarima \& Hamdan, 2011). Consequently, many students in Indonesia have very poor English proficiency although they have studied English for years (Mattarima \& Hamdan, 2011).

In addition, English is not used to communicate in daily communication. It is mostly used in special situations in which international interactions are conducted (e.g. international business meetings). However, the urgency of having good English ability has increased more and more recently. English has become one of the important requirements mentioned in many job vacancies and scholarship applications. Therefore, effective English learning processes are hoped to create successful, proficient English learners.

Due to the limited English exposure received by the students inside the classroom, the practice of outof-class language learning (OCLL, henceforth) is considered useful to give students more exposure (Marefat \& Barbari, 2009) and to help them master English better. Cotterall and Reinders (2001) mentioned that to acquire good English ability, students are supposed to conduct OCLL to complement in-class learning. To create a successful OCLL process, students need to use out-of-class language learning strategies (OCLLSs, henceforth) that suit their needs. OCLLSs in this study include 
any activities done or strategies used for improving English ability outside the English classroom (Cheng, 2015).

There have been a lot of research studies conducted to investigate the types of OCLLSs used for learning English either in ESL or in EFL contexts. Murray (2008) examined eight Japanese EFL learners, and reported that the learners were likely to use OCLLSs related to receptive skills (e.g. listening to English songs). The same findings that put high priority to the receptive skills related strategies were found in the studies conducted by Pearson (2004), Hyland (2004), Murray (2008), Marefat and Barbari (2009), and Cheng (2015).

On the other hand, Lamb (2002) investigated 16 Indonesian students at University of Jambi, and found that the most frequent activities used by the students to learn English outside the classroom were speaking and reading activities, with middle-high achieving students as the dominant users. Similar findings on the preferences of using both receptive and productive skills were also found in Maros and Saad's (2016) study. The appropriate use of OCLLSs has been reported to have created a successful English language learning and improve the students' English language proficiency (Griffiths, 2003; Oxford, 2002 cited in Marefat \& Barbari; and Mistar \& Umamah, 2014).

Regarding the use of mediation in learning, some researchers have conducted research to identify the ways of performing OCLLSs. In their research, Maros and Saad (2016) concluded that the participants liked using 'technology related tools' better than using other people or participants themselves while learning English. Similar findings on the use of technology-affiliated tools were also reported by Lai and Gu (2011) and Saad, Yunus, and Embi (2013), which then specified the benefits of using technology along with OCLLSs to facilitate English learning outside the classroom. On the other hand, Doyle and Parrish (2012) reported that Japanese students who participated in their research preferred using "traditional ways of using English outside of class, studying for tests for example" (p.200).

Although the use of OCLLSs has been considered effective to support the success of OCLL, which then improves the students' English ability (Oxford, 2002 cited in Marefat \& Barbari, 2009; Griffiths, 2003; Mistar \& Umamah, 2014), the studies on this topic are still limited compared to the classroom language learning studies (Benson, 2011). Many EFL learners are not familiar with the idea of learning strategies, particularly OCLLSs (Lamb, 2002; Marefat \&
Barbari, 2009; Doyle \& Parrish, 2012). Therefore, the studies on OCLLSs are still important to be conducted to give in depth understanding of OCLLSs to EFL learners so that they can take advantage of the use of OCLLSs for improving their English ability.

This study was designed to investigate the types of OCLLSs and the ways of performing OCLLSs chosen by six English majors in Indonesia when learning English, using seven-day journals and emailbased interview. For achieving the research purpose, two research questions were formulated, i.e.:

1. What language learning strategies do English majors use when learning English outside the classroom in Indonesia?

2. How do they perform the strategies?

\section{METHODS}

This study is qualitative research with case study form. It examined the types of OCLLSs employed by Indonesian students and the ways that they use in performing the strategies. In choosing the participants, the study used purposive sampling procedure. The researcher chose "participants who meet some specific predetermined criteria" (Dornyei, 2007 , p. 128). The participants involved in this study were required to have a minimum of GPA 3.00 and be 8th semester students who were doing teaching practice. The participants were six English majors at a university in Indonesia, with intermediate-upper intermediate level of English proficiency and aged 20 to 21 . The participants were then given pseudonyms for confidentiality purpose.

Two types of instruments, learner journal and email-based interview, were used to collect the data. The participants involved were firstly asked to write a seven-day journal. Then, they were interviewed through email after they finished writing the journals. The journals were used to gather information about the kinds of OCLLSs used, the skills involved, the ways of performing OCLLSs, and the participants' learning reflections. Meanwhile, the email-based interviews were employed to collect the participants' personal information and to confirm the information collected from the journals. Both journal table and ten interview questions were sent to the participants' emails. The guidance of journal writing and the interview questions were derived from Hyland's (2004) study and the researcher's pilot study with some adaptation. The instruments validity and reliability were checked by using two methods proposed by Dornyei (2007): participants' feedback and peer checking process.

There were five themes used to analyse the types of OCLLSs as the ones used by Maros and Saad (2016), i.e. reading, listening, writing, speaking, and 
watching. Furthermore, three themes used to analyse the ways of performing OCLLSs were also derived from Maros and Saad (2016), i.e. employing tool, involving other people, and being self-directed. According to Dornyei (2007), analytical processes used to analyse the qualitative data included "transcribing the data, pre-coding and coding, growing ideas - memos, vignettes, profiles, and other forms of data display, and interpreting the data and drawing conclusions" (p. 246). Therefore, this study used the processes mentioned closely, except the process of transcribing data because the interview data collected were not spoken data.

\section{RESULTS AND DISCUSSION}

\subsection{Findings}

\subsubsection{English majors' OCLLSs}

There were five themes revealed from the learners' journals regarding the types of OCLLSs used by the participants in this study (see Table 1).

Table 1. OCLLSs and the Frequency of Occurrences Reported

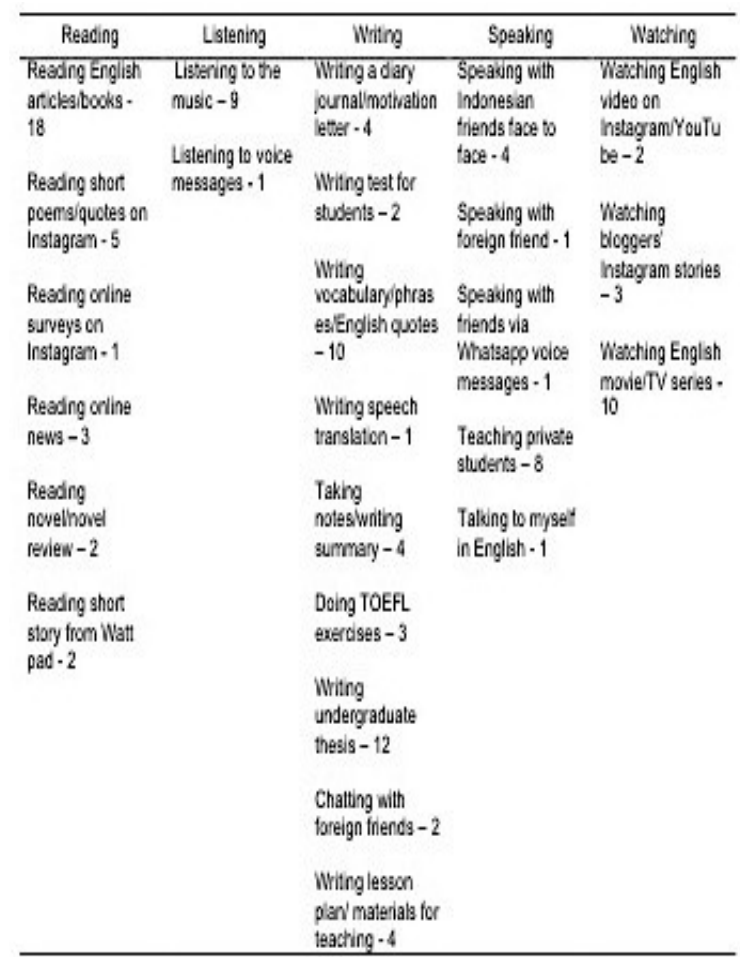

Strategies related to writing skills were reported as the most frequent strategies used with 42 times occurrences. Reading-related strategies came second and occurred 31 times. Meanwhile, strategies related to speaking and watching occurred for the same numbers of time, i.e. 15 times. Lastly, strategies related to listening seemed to be the least frequent strategies used by the participants with 10 times occurrences (see Table 2).

Table 2. The Frequency of OCLLSs Occurrences Based on the Focused Skills

\begin{tabular}{lllll}
\hline Reading & Listening & Writing & Speaking & Watching \\
\hline 31 & 10 & 42 & 15 & 15 \\
\hline
\end{tabular}

From these results, it can be concluded that the two most common strategies used by six English majors in Indonesia were writing- and reading-related strategies. The types of strategies chosen to improve the participants' writing and reading skills included some activities, such as writing undergraduate thesis, reading novel, and so forth (see Table 1).

\subsubsection{Ways of Performing OCLLSs}

There were three ways of performing OCLLSs chosen by the participants, i.e. using tool, involving other people, and being self-directed (see Table 3 ).

Table 3. The Ways of Employing the OCLLSs

\begin{tabular}{|c|c|c|c|}
\hline \multicolumn{2}{|c|}{ Using tool } & \multirow{2}{*}{$\begin{array}{l}\text { Involving } \\
\text { other }\end{array}$} & \multirow{2}{*}{$\begin{array}{l}\text { Being } \\
\text { self- } \\
\text { directed }\end{array}$} \\
\hline $\begin{array}{l}\text { Modern } \\
\text { Tech. }\end{array}$ & $\begin{array}{l}\text { Traditional } \\
\text { Tech. }\end{array}$ & & \\
\hline 32 & 19 & 9 & 1 \\
\hline Total: 51 & & Total: 9 & Total: 1 \\
\hline
\end{tabular}

Based on the result of analysis, 'using tools' was the most popular way chosen by the participants when they used OCLLSs, with 51 times occurrences. It was focused more on the use of technology-affiliated tools, computer and Instagram for examples, than traditional ones. It was confirmed by the comments of some participants in their interview:

The best one is learning though Instagram because I like Instagram very much. I do not just see picture but in the time I enjoy the feeds I can learn English intentionally from English account and see authentic English as well. (Samha)

I think listening a video of mp3 is most useful, because my weakness is in this skill. (Delima)

Then, 'involving other people' came second and occurred 9 times. Lastly, 'being self-directed' was reported as the least preferred way chosen by the participants in this study. To conclude, students seem to have understood the benefit of using tools, especially the ones related to technology, in facilitating and helping their learning.

\subsection{Discussion}

The two most common strategies found in this study were writing and reading associated strategies. 
It was similar to the results revealed in the study conducted by Lamb (2002) in Indonesia and Maros and Saad (2016) in Malaysia in terms of the focused skills group, i.e. a mix of productive and receptive skills.

However, the findings in this study were different from the findings reported by Murray (2008), Hyland (2004), Marefat and Barbari (2009), Pearson (2004), and Cheng (2015) which found that participants in their studies were likely to use receptive skills than productive ones. It was clear that the participants in this study used various OCLLSs to support their OCLL, especially the ones related to writing and reading skills which the participants reported as the two most frequent skills used to complete their tasks as final semester students.

In regard to the ways used to perform OCLLSs, it was found that 'using tools' was the most popular way chosen by the participants. They preferred using tools related to modern technology to the traditional ones. It was similar to the findings found in the research conducted by Maros and Saad (2016), Lai and $\mathrm{Gu}$ (2011), and Saad et al., (2013). However, it was different from the result found by Doyle and Parrish (2012) which mentioned that their participants used more traditional ways that utilized traditional technology affiliated tools.

The study findings inform the readers to take advantages of OCLLSs in teaching and learning process. EFL students can get insights of the OCLLSs types they can use to improve their English skills. It also gives EFL teachers information about the importance of OCLLSs for students, which further gives teachers knowledge on how to vary the classroom activities and choose the teaching strategies that suit the students.

There are some limitations in this study and thus need some future improvements. First, the number of students participated in this study was considered too few. Thus, a larger number of samples used in future research are hoped to give better findings. Second, the use of email-based interview as one of the data collection methods was less effective because it gave participants space to skip or miss some questions. Lastly, the use of single research method prevented the researcher from generalizing the results of this study. Therefore, the use of mixed methods may give better, more varied results.

\section{CONCLUSIONS}

To sum up, there were two findings found in this study. First, the two most common strategies used were strategies related to writing and reading skills (mixed-skills). Second, the students preferred using modern technology-affiliated tools (e.g. computer, Instagram) tools when performing OCLLSs. Another upcoming research is obviously required and one interesting topic to investigate will be the effects of OCLLSs towards Indonesian students' language learning and development. Also, it is interesting and challenging to research the benefit of using OCLLSs on different major students.

\section{REFERENCES}

Dornyei, Z. (2007). Research methods in Applied Linguistics. Oxford: Oxford University Press.

Doyle, H., \& Parrish, M. (2012). Investigating students' ways to learn English outside of class: A researchers' narrative. Studies in Self-Access Learning Journal, 3(2), 196-203.

Griffiths, C. (2003). Patterns of language learning strategy use. System, 31, 367-383.

Hyland, F. (2004). Learning autonomously: Contextualising out-of-class English language learning. Language Awareness, 13(3), 180-202.

Lai, C., \& Gu, M. (2011). Self-regulated out-of-class language learning with technology. Computer Assisted Language Learning, 24(4), 317-335.

Lamb, M. (2002). Explaining successful language learning in difficult circumstances. Prospect, 17(2), 35-52.

Marefat, F., \& Barbari, F. (2009). The relationship between out-of-class language learning strategy use and reading comprehension ability. Porta Linguarum, 12, 91-106.

Maros, M., \& Saad, N. S. M. (2016). The out-of-class language learning strategies of international students in Malaysia. International Journal of Asian Social Science, 6(8), 478-486.

Mattarima, K., \& Hamdan, A. R. (2011). The teaching constraints of English as a foreign language in Indonesia: The context of school based curriculum. Sosiohumanika, 4(2), 287-300.

Mistar, J., \& Umamah, A. (2014). Strategies of learning speaking skill by Indonesian learners of English and their contribution to speaking proficiency. TEFLIN Journal, 25(2), 203-215.

Murray, G. (2008). Pop culture and language learning: Learners' stories informing EFL. Innovation in Language Learning and Teaching, 2(1), 2-17.

Novera, I. A. (2004). Indonesian postgraduate students studying in Australia: An examination of their academic, social, and cultural experiences. International Education Journal, 5(4), 475-487.

Pearson, N. (2004). The idiosyncrasies of out-of-class language learning: A study of mainland Chinese students studying English at tertiary level in New Zealand. Paper presented at the Independent Learning Conference 2003, Melbourne, Australia.

Saad, N. S. M., Yunus, M. M., \& Embi, M. A. (2013). The intersection between out-of-class language learning strategies and in-class activities. Advances in Language and Literacy Studies, 4(2), 132-139. 